PLEASE QUOTE FROM THE PUBLISHED VERSION: Abena Oduro and Irene van Staveren (2015) "Engendering Economic Policy in Africa", Feminist Economics 21 (3), pp. 1-22.

\title{
Engendering ECONOMic Policy in AfRica
}

\author{
Abena D. Oduro and Irene van Staveren
}

\begin{abstract}
Despite Africa's relatively commendable growth performance since 2000, growth has not been accompanied by structural transformations. First, there has been little diversification from agriculture into industry, particularly manufacturing. Second, the poverty headcount and inequality remain high in many countries, even as African countries continue to rank lowest on the United Nations Development Programme's Gender Inequality Index. This contribution goes beyond the individualistic approach of supply-side policies and unveils deeper mechanisms that need to be tackled for the two transformations (diversification and inequality reduction) to occur. It demonstrates that gender inequality relies on unwritten but dominant social norms, hence, informal institutions. The removal of formal legislation that constrains women's agency, the enactment of formal laws, and the implementation of economic policies designed specifically to create incentives for behavior change are recommended.
\end{abstract}

\section{KEYWORDS}

Structural transformation, gender inequality, informal institutions, Africa

JEL Codes: D63, O55 


\section{RUNNING HEADER: ENGENDERING ECONOMIC POLICY IN AFRICA}

\section{INTRODUCTION}

Compared to other regional and economic blocs, Sub-Saharan Africa's growth since 2000 is laudable. Commodity price increases and improved macroeconomic conditions have fueled this growth (African Development Bank Group [AfDB] 2013; United Nations Economic Commission for Africa [UNECA] 2015. ${ }^{1}$ The sub-continent has grown faster than the advanced economies and Latin American and Caribbean countries since the mid-1990s (Figure 1). The gap between the African and advanced economies' growth rates widened in the 2000s. This is because of the global and financial crises of 2007-8, which hit the advanced economies harder due to their intense financialisation and financial interconnectedness between their banks. This has resulted in a sharper decline in advanced economy growth rates than for African economies.

Despite this relatively commendable growth performance, an important issue remains on the agenda that could reverse the growth trends. Growth has not been accompanied by structural transformations. We notice two structural transformations, which have been realized - at least partially - in Latin American growth since 2000, have been weaker in African growth, even though growth in both regions was driven by the commodities boom. The first structural transformation involves diversification out of agriculture and into industry, in particular manufacturing. Agriculture's share of the gross domestic product (GDP) remained virtually 
PLEASE QUOTE FROM THE PUBLISHED VERSION: Abena Oduro and Irene van Staveren (2015) "Engendering Economic Policy in Africa", Feminist Economics 21 (3), pp. 1-22.

unchanged between 2005 and 2012 increasing from 15 to 16 percent. Industry's share declined from 39 to 35 percent, while that of manufacturing declined by 2.4 percentage points to about 10 percent. The services sector's contribution increased from 46 to 49 percent over the same period (African Development Bank Group, African Union Commission, and Economic Commission for Africa 2014). These averages mask differences among African countries. Ghana registered a significant decline in agriculture's contribution to GDP, which declined to 23 percent in 2012. Meanwhile the services sector's share rose to 50 percent. This contrasts with Togo and Mali, which recorded increases in agriculture's share of GDP. Only twelve out of fifty-three countries recorded some increase in the share of manufacturing to GDP.

Figure 1 Growth rates for selected regional and economic blocs

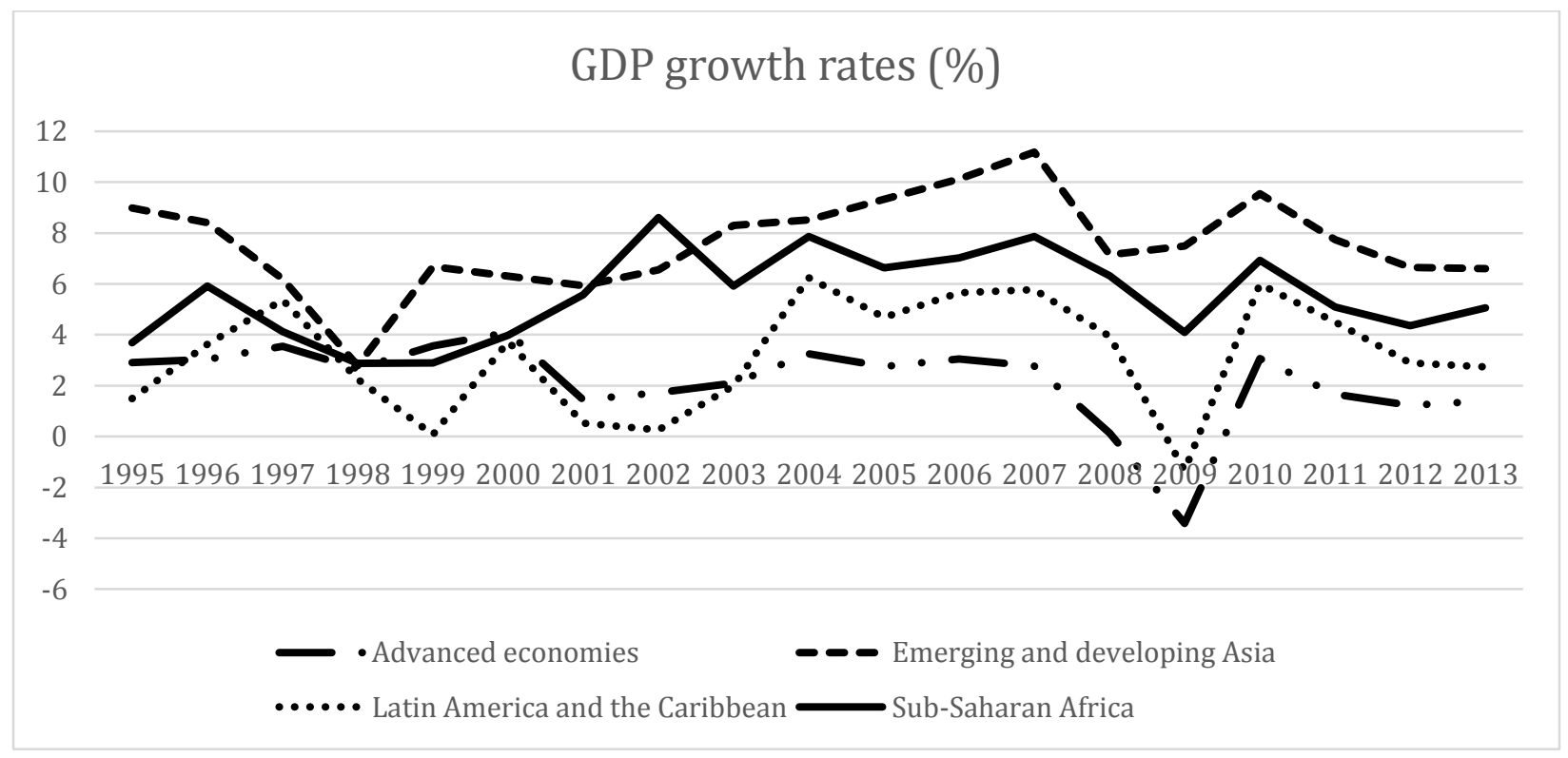

Source: IMF World Economic Outlook Database October 2014. 
PLEASE QUOTE FROM THE PUBLISHED VERSION: Abena Oduro and Irene van Staveren (2015) "Engendering Economic Policy in Africa", Feminist Economics 21 (3), pp. 1-22.

Growth based on the rise of commodity prices will not be sustained if the excess revenues are not adequately invested in broadening the basis of growth. Indeed, as Figure 1 shows, Africa's growth rates have not been maintained since 2010 . Thus, growth strategies that broaden the sources of growth away from reliance on commodity price booms will increase the likelihood that growth will be sustained. Moreover, growth that is not widely shared in society but is accompanied by rising inequality can create, and in fact has created, conditions for conflict.

The second transformation lacking in African economic growth is that of substantial poverty reduction and lower levels of inequality. Sub-Saharan Africa has the lowest growth elasticity of poverty among all regional groupings largely due to its low-income levels and high inequality (Augustin K. Fosu 2011). ${ }^{2}$ The poverty headcount remains high despite its decline since 2005, and inequality remains high in many African countries (AfDB 2012). African countries continuously have the lowest level of human development and the worst Gender Inequality Index (United Nations Development Programme [UNDP] 2014). In 2013, the Gender Inequality Index for Africa stood at 0.578, higher than that of Arab countries (0.546) and South Asia (0.539) (UNDP 2014). The UNDP Africa Human Development Report 2012 reveals that hunger is most widespread in this region of the world, and economic growth in Africa has had almost no effect on under-nutrition (UNDP 2012). This failure has a clear gender dimension. Kenneth Harttgen, Stephan Klasen, and SebastianVollmer (2012) found that the most important factor for reducing child under-nutrition in Africa is women's empowerment. Education and socioeconomic status of mothers, as well as their own levels of nutrition following these achievements, are the strongest determinants for reducing child under-nutrition.

The post-2015 global poverty reduction goal pushed by nongovernmental organizations (NGOs) and the World Bank in the Zero Poverty 2030 campaign is quite ambitious. ${ }^{3}$ By the year 
PLEASE QUOTE FROM THE PUBLISHED VERSION: Abena Oduro and Irene van Staveren (2015) "Engendering Economic Policy in Africa", Feminist Economics 21 (3), pp. 1-22.

2030, poverty (measured as the number of people living on under 1.25 US dollars per day) in developing countries should be zero or at least below 3 percent. In order to achieve this goal, economic growth in developing countries should not only be relatively high and stable (around 4 percent), but it should also benefit the bottom 40 percent more than the top 60 percent, according to a recent World Bank study (Christoph Lakner, Mario Negre, and Espen Beer Prydz 2014). Only when the income growth of the bottom 40 percent is 2 percent faster than that of the rest will the poverty elimination goal be achieved in time for the 2030 deadline. But, the authors of the study warn, even with fifteen years of a steady 2 percent higher income growth among the 40 percent poorest population, the poverty elimination goal will not be met in Sub-Saharan Africa. Instead, under such favorable growth conditions, the poverty rate in Sub-Sahara Africa will get down to 15 percent, which is a long way from 3 percent, let alone 0 percent. Therefore, in SubSaharan Africa, even more ambitious policies of social inclusion are required as compared to Asia and Latin America. Sub-Saharan Africa needs growth with structural and social transformations.

Social policies of inclusion must explicitly include measures to reduce gender inequality. The nature of the link between gender inequality and growth in Africa depends on the dimension of gender inequality that is being considered and the structure of the economy (Stephanie Seguino and Maureen Were 2014). In low-income, agricultural economies where women are concentrated in food production and off-farm waged labor, Seguino and Were (2014) posit that a reduction in wage inequality is likely to have a positive effect on economic growth in Africa. This is because of the expansionary effect that an improvement in women's wages will have because of women's higher marginal propensity to consume. Gender inequality in education reduces growth in Sub-Saharan by about 3.5 percentage points - below that of East Asia and the 
PLEASE QUOTE FROM THE PUBLISHED VERSION: Abena Oduro and Irene van Staveren (2015) "Engendering Economic Policy in Africa", Feminist Economics 21 (3), pp. 1-22.

Pacific (Stephan Klasen and Francesca Lamanna 2009). Micro-level studies also provide evidence on the relationship between gender inequality and output. For example, Markus Goldstein and Christopher Udry (2008) find that political power in rural farming communities in Ghana is positively associated with security of land tenure and land rights. Women are less likely to have political power and are therefore less likely to invest in their farms when they do not have security of tenure, thus resulting in lower yields.

The recognition of the need for the two transformations - a broader basis for growth away from commodity price booms and more benefits from growth for the poor - has informed the long-term strategy of the African Development Bank Group for the period of 2013-22. The two objectives of its strategy are inclusive growth and the promotion of sustainable growth. The AfDB defines inclusive growth as "broad-based growth across sectors" that takes into account “age, gender, regional or geographical gaps and balances as well as sectoral differences and balances" (AfDB 2012: 2). Similar concerns about insufficient inclusiveness in Africa's recent growth episode were echoed by the Managing Director of the International Monetary Fund (IMF) in her keynote address at the Africa Rising conference held in Maputo, Mozambique in May 2014. She observed: "the tide of growth has not lifted all boats," and "when everyone benefits, growth is more durable" (Christine Lagarde 2014). The first report on economic transformation from the African Center for Economic Transformation bemoaned that Africa was experiencing growth without DEPTH (ACET 2014). ${ }^{4}$ DEPTH is an acronym for diversification, export competitiveness, productivity, technological change, and human well-being.

These different players in Africa's development arena may have different priorities and strategies for structural transformation in Africa, but they all agree that Africa cannot continue along its current path. Both the AfDB in its 2013-22 strategy and the IMF explicitly recognize 
PLEASE QUOTE FROM THE PUBLISHED VERSION: Abena Oduro and Irene van Staveren (2015) "Engendering Economic Policy in Africa", Feminist Economics 21 (3), pp. 1-22.

the importance of targeting and prioritizing women, youth, and children in their agendas. The AfDB's strategy aims at "broadening economic opportunities for women," (AfDB 2013:11) while the IMF recommends that Africa must "invest in women" (Lagarde 2014). ACET recognizes that human well-being involves raising incomes, reducing poverty and inequality, and creating conditions for peace, justice, and security. Unfortunately, its indicators of human wellbeing, such as GDP per capita and the share of formal employment in total employment, are not appropriate or adequate to ensure that issues of poverty and inequality along any dimension, (for example: class, ethnicity, gender, religion, or geography) are dealt with. The four pathways to economic transformation ACET proposes (labor intensive manufacturing; agro-processing; oil, gas, and minerals; and tourism) will have issues of gender inequality embodied within them that should be explicitly addressed if economic transformation is to be inclusive. The large development institutions clearly show awareness that women's empowerment is key to inclusive and sustainable growth in Africa. But neither the World Bank, IMF, the AfDB, nor ACET shows a systematic understanding and policy agenda of how this can be achieved. They simply reduce the complexities of gender relations in African economic development to supply-side policies of investment in women.

This special issue provides detailed insights into how gender relates to economic development in the African context. It goes beyond the standard supply-side policies of investing in women's education or improving access to land and credit. Instead, the contributions in this special issue reveal several gendered mechanisms that are often ignored by economic policymakers. These appear to be crucial for triggering the two transformations economic growth in Africa has been lacking up to now. 
PLEASE QUOTE FROM THE PUBLISHED VERSION: Abena Oduro and Irene van Staveren (2015) "Engendering Economic Policy in Africa", Feminist Economics 21 (3), pp. 1-22.

\section{THE GENDERED CONSTRAINTS TO ECONOMIC DEVELOPMENT IN AFRICA}

The eight articles in this special issue point at four gendered mechanisms at the micro and macro level. They go beyond the individualistic approach of supply-side policies and unveil deeper mechanisms that need to be tackled for the two growth transformations to occur. Supply-side policies focus on increasing women's individual resources, such as education and credit. These are obviously necessary economic strategies to reduce both gender inequality and poverty and social exclusion. However, supply-side policies are not a sufficient strategy because they ignore other dimensions of the capabilities approach and the social economics of development. These dimensions involve social norms and legal constraints, which can be summarized as informal and formal institutions. They also involve continued mechanisms of redistribution: of land, wealth, labor income, and social benefits. Redistribution is insufficient when it is carried out as a oncetime-only policy, such as land reform or universal primary education, because product markets and labor markets have their own accumulation processes, segmentation and discrimination. Hence, from a social economics perspective, redistribution needs to be firmly institutionalized as a continuous process, for example through progressive taxation, subsidies for disadvantaged groups and policies addressing discrimination and social exclusion. Moreover, gender equality is not just about more access to resources for girls and women - as if we lived in a world of plenty. Gender equality often implies less of the same resource provided to boys and men, as shown by gender budget analyses. Finally, gender equality is not only an individual process, but, importantly, it is also a social process. It involves women's socially defined roles as caregivers for others in the household and community and involves collective agencies of women defining the capabilities they want to achieve. Various capabilities are not of individual character but are, 
PLEASE QUOTE FROM THE PUBLISHED VERSION: Abena Oduro and Irene van Staveren (2015) ’Engendering Economic Policy in Africa”, Feminist Economics 21 (3), pp. 1-22.

instead, interdependent: such as the capabilities of intellectual and social debate and the capabilities of dignity and respect. Supply-side policies targeting individual women's resources are not the best-suited strategies to address such social-level capabilities and women's collective agency to formulate and claim these capabilities.

Next, the four gendered constraints will be discussed in relation to the articles in this special issue.

\section{Constraint 1: Women's lack of ownership and control over assets}

African women's lack of access to land, housing, and other property rights (relative to men) is well-known. For example, in Ghana, women own 30 percent of gross household physical wealth (Abena D. Oduro, William Baah-Boateng, and Louis Boakye-Yiadom 2011). The incidence of ownership of agricultural land, place of residence, other real estate, and livestock is lower among women than among men. The incidence of business ownership is higher among women. However, men own larger businesses. African women have the weakest ownership rights compared to women in other regions of the world (see Figure 2). It is also well-known that this constrains women's investment in agriculture (Goldstein and Udry 2008) and limits their decision making in the household (Cheryl Doss 2006). But what about households where husband and wife experience joint ownership? Does this automatically lead to equal control over assets? For example, does this lead to women being able to make decisions about land use for the benefit of household food security? 
PLEASE QUOTE FROM THE PUBLISHED VERSION: Abena Oduro and Irene van Staveren (2015) "Engendering Economic Policy in Africa", Feminist Economics 21 (3), pp. 1-22.

Krista Jacobs and Aslihan Kes (2014; this volume) study precisely this topic in Uganda and South Africa. In their survey, 10 percent of couples stated joint land ownership, and 26 percent stated joint house ownership. Comparing women with no perceived ownership, women with perceived joint ownership, and women with perceived sole ownership, Jacobs and Kes reveal that perceived joint ownership does not provide much decision-making power to women compared to the category of no perceived ownership. So, perceiving that household property is shared, either because this is legally the case or marriage implies this to be the case, apparently has little effect on actual decision-making influence by women over such joint property. In contrast, women who stated they had sole ownership appeared to have stronger decision-making power over their property as compared to women stating they had joint ownership. In practice, men had more decision-making power over the land and house than their wives, even when both agreed that the assets were jointly owned. This finding implies that gender equality in the household in ownership does not automatically translate into joint decision making about these assets, even when men agree that their wives equally share ownership. These findings confirm the implications from other empirical studies on Africa that joint assets do not necessarily lead to decision-making power for women as compared to exclusive male-ownership of assets (Cheryl Doss, Chiara Kovarik, Amber Peterman, Agnes Quisumbing, and Mara van den Bold 2015). Thus, land reform and titling of assets to couples in Uganda and South Africa - but likely also in other countries in Sub-Saharan Africa - does not seem to challenge male authority in decision making about assets. Without legal enforcement of women's individual ownership rights and without a change in gender norms about decision making in the household, a seemingly genderequal policy of joint titling has little effect on women's empowerment and little effect on 
PLEASE QUOTE FROM THE PUBLISHED VERSION: Abena Oduro and Irene van Staveren (2015) "Engendering Economic Policy in Africa", Feminist Economics 21 (3), pp. 1-22.

investment choices in land for the sake of the well-being of all members of the household, including children.

Figure 2 Women's ownership rights per region of the world

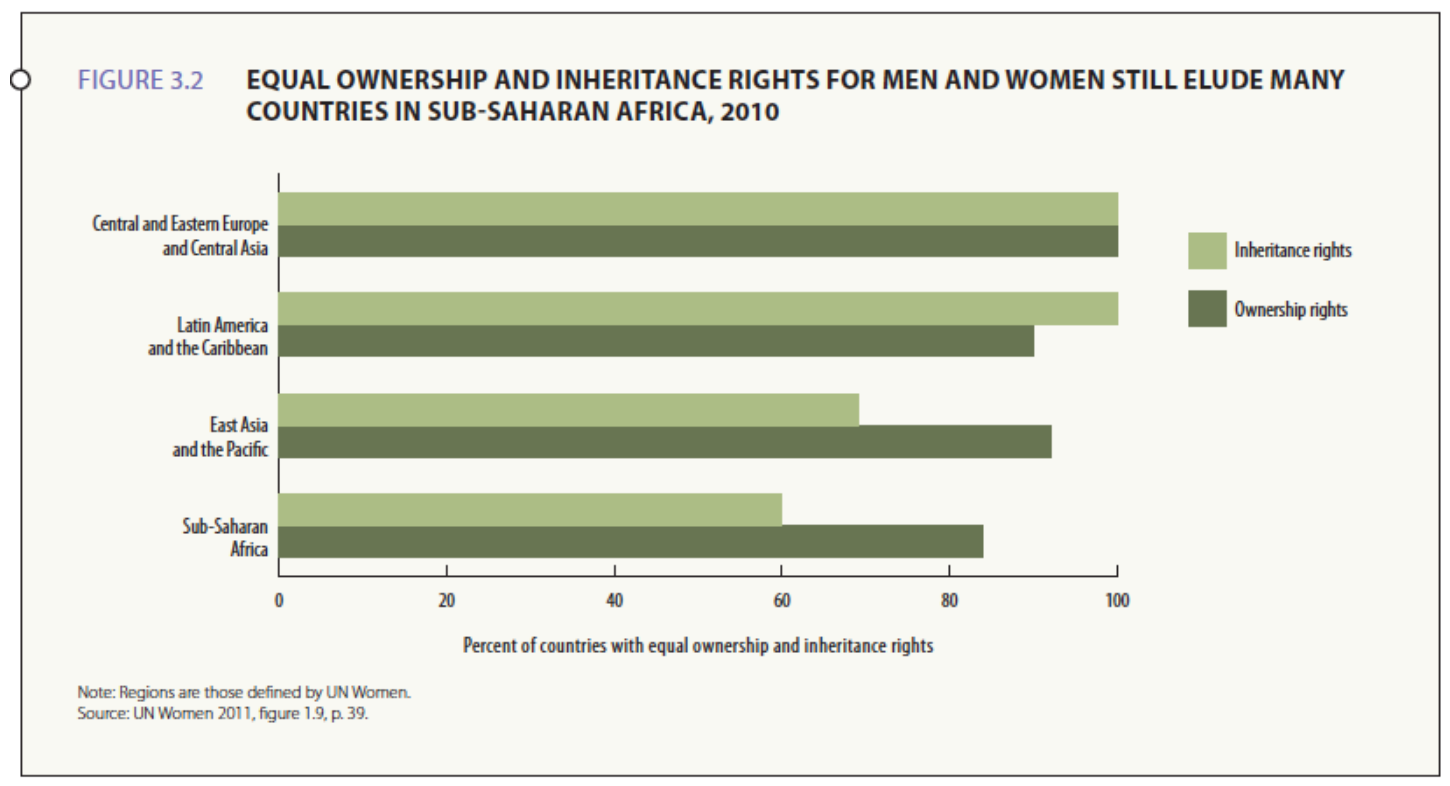

Source: UNDP (2012: 49).

Yetunde Aluko (2015; this volume) looks into the decision-making power of Yoruba women in Nigeria when they actually do have individual property, such as land and houses. She finds that even when women acquire property, their husbands also exercise control over these assets. ${ }^{5}$ Therefore, is women's individual property ownership not the solution to the problem (as sketched by Jacobs and Kes)? Aluko's response to this question is both yes and no. Yes: because there is at least a formal recognition - by the state and by market parties - of women's ownership rights. This formal recognition of land rights is indeed what other authors emphasize to be important (see, for example, a special issue of Feminist Economics, edited by Cheryl Doss, Gale Summerfield, and Dzodzi Tsikata [2014], on land, gender, and food security). But at the same 
PLEASE QUOTE FROM THE PUBLISHED VERSION: Abena Oduro and Irene van Staveren (2015) "Engendering Economic Policy in Africa", Feminist Economics 21 (3), pp. 1-22.

time, the answer is no: individual asset ownership does not necessarily provide women with decision-making power vis-a-vis their male partners. This is because the idea of deriving bargaining power from individual assets in the household goes against patriarchal norms, in particular when women acquire property through the market with their own income, as Aluko (2015) demonstrates. Such individualism is simply rejected in Nigeria, a country that, according to an international value overview by Geert Hofstede (2001), ranks among the lowest in the world on values of individualism versus collectivism. Assets obtained through inheritance give more decision-making power to women because wealth accumulation through (family-based) inheritance is more socially accepted than that gained through (individual-based) market transactions. Inheritance does not involve agency but just happens as a positive, exogenous shock to household wealth. As soon as wealth acquisition by women occurs through their own agency, it is often not socially approved and hence, does not deliver the decision-making power individual asset ownership is supposed to deliver. Aluko's findings indirectly support the findings by Jacobs and Kes. All agree that both joint assets and individual ownership do not deliver in terms of women's decision-making power due to dominant social norms about men being the main decision maker when assets in the household are concerned.

Both the studies - covering Uganda, South Africa, and Nigeria - point out that simply investing in women, whether it is through joint assets ownership or individual property rights, will not bring about the transformations of broader-based growth and more widely shared benefits from growth. When men remain in charge of decision making about assets and their behavior is socially legitimized, women's own choices, related to their distinct roles as food providers and childcare givers, will not affect the actual use of land and other household 
PLEASE QUOTE FROM THE PUBLISHED VERSION: Abena Oduro and Irene van Staveren (2015) "Engendering Economic Policy in Africa", Feminist Economics 21 (3), pp. 1-22.

property. As a consequence, long-standing poverty-related issues in Africa, such as child undernutrition, are not likely to be addressed.

\section{Constraint 2: Unequal and high burden of unpaid work}

African women spend more time than men on unpaid household chores and caring for household members and less time than men on subsistence or labor market work (Marzia Fontana and Luisa Natali 2008; Elena Bardasi and Quentin Wodon 2010; Maria S. Floro and Hitomi Komatsu 2011). The gender division of labor that makes women and girls responsible for household chores and unpaid care work and the lack of basic infrastructure such as pipe-borne water and electricity can explain the long hours women spend on unpaid domestic work. Evelyn F. Wamboye and Stephanie Seguino's (2014) contribution in this special issue shows how important it is that the unpaid work burden of women is reduced. Their cross-country analysis of employment effects of trade liberalization shows that contrary to the experience in Asia, trade liberalization in Sub-Saharan Africa has had negative employment effects for women. In particular, manufacturing exports and imports lower women's employment in non-resource rich countries. Only food exports increase women's jobs. The major interpretation the authors provide is that trade liberalization is part of a larger package of neoliberal policies, which includes a reduction of public expenditures. Lower investment in public infrastructure was correlated with lower employment for women; this is probably because it increases unpaid work burdens for women in terms of healthcare, water and energy supply, and other time-consuming tasks. That being said, neoliberal policies may push for some economic diversification; however, 
PLEASE QUOTE FROM THE PUBLISHED VERSION: Abena Oduro and Irene van Staveren (2015) ’Engendering Economic Policy in Africa”, Feminist Economics 21 (3), pp. 1-22.

women do not benefit when such policies include a reduction in social infrastructure

expenditures. The private sector does not step in to reduce unpaid work burdens for women, and men do not automatically share in these tasks.

Whereas Wamboye and Seguino have (2014) focused on public goods as a way to reduce women's unpaid work burden, Apollo M. Nkwake's (2015) contribution in this volume focuses on a more equal distribution of unpaid work between women and men. Using data from Uganda, Nkwake shows that fathers are most likely to share in childcare when they perceive that the mother's wealth and their own are more or less equal. When fathers are richer than mothers, they are less likely to participate in childcare. That is because this reinforces a traditional division of labor in which the mother is solely responsible for childcare. Even more interesting is Nkwake's finding that when mothers are wealthier than fathers, fathers are equally unwilling to participate in childcare. In that case, a traditional gender division of labor in childcare is reinforced by a reassertion of the traditional gender role of a male breadwinner. Men simply stick to the masculine domain of income earning: all the more so when they feel their breadwinning role is threatened by their wife's income. The study shows that when fathers perceive the wealth distribution in the household as equal, they are most likely to do childcare work. At the same time, when mothers also perceive the wealth distribution in the household as equal, they are more likely to support fathers' involvement in childcare. So, when both men and women earn incomes, when they share in the household wealth more or less equally, and both perceive this also subjectively, gender norms about the division of labor are most likely to change. In contrast, with unequal wealth distribution, stereotypical gender norms about roles in the household tend to be reinforced. This finding about balance in resources between the partners was also found for 
PLEASE QUOTE FROM THE PUBLISHED VERSION: Abena Oduro and Irene van Staveren (2015) "Engendering Economic Policy in Africa", Feminist Economics 21 (3), pp. 1-22.

other determinants of household bargaining in a household survey in Ethiopia (Ramzi Mabsout and Irene van Staveren 2010).

Nkwake's study provides a very interesting insight into the momentum for change of gender norms. The momentum for a more equal share in childcare responsibilities stems from mothers having more wealth without, however, tipping the balance toward too much wealth - as is sometimes the case in women-targeted credit programs. When equality becomes the norm in terms of a household's assets, it can easily become the norm for the distribution of childcare as well. A change in the gender norm about husbands as breadwinners and wives as caregivers is not only important for social inclusion and gender equality, but also for economic growth. Irene van Staveren (2014) found that adherence to the social norm, or that "men have more rights to a job than women in times when jobs are scarce," has a statistically and relatively large negative impact on economic growth in a cross-country study. A norm change toward greater gender equality in the gendered division of labor is likely to benefit growth as well.

\section{Constraint 3: Undermining social cohesion and ignoring women's leadership}

In Africa as well as elsewhere in the developed world, women are under-represented in leadership positions. Many countries therefore have designed policies to increase the share of women in leadership positions, both in the public and private sector. Kenya's policy of requiring at least 33 percent of each gender on the boards of state-owned enterprises is a good example. Rwanda's parliament has succeeded in exceeding the 2003 constitutional requirement that at least 30 percent of decision-making positions are occupied by women. But how does more 
PLEASE QUOTE FROM THE PUBLISHED VERSION: Abena Oduro and Irene van Staveren (2015) "Engendering Economic Policy in Africa", Feminist Economics 21 (3), pp. 1-22.

gender balance in leadership roles contribute to the two transformations of diversification of production and poverty reduction? The study by Els Lecoutere, Ben d'Exelle, and Bjorn van Campenhout (2015) in this volume sheds some light on this. They conducted a field experiment in Tanzania with a distribution game about irrigation water. The study analyzed the distribution rules of upstream living low-status versus high-status men and women with and without the condition of water scarcity. The results indicate that overall, low-status individuals distributed irrigation water equally with downstream populations when there was no scarcity, but kept more for themselves, depriving those living downstream from sufficient irrigation water under the condition of water scarcity. This is explained by a lack of diversification in the livelihoods of low-status individuals: with less water, they could not achieve minimum livelihood standards. Low-status women appeared to be a bit more generous than low-status men. For high-status individuals, large gender differences appeared. High-status men kept more water for themselves both when water was abundant and when it was scarce. In contrast, high-status women were the most generous group when water was abundant, giving more than an equal share to those living downstream. When water was scarce, they gave an equal share. The authors therefore recommend that higher-status women should be given leadership roles in joint-resource governance bodies. Not only because this is fair to women, but also because they enforce fairness norms in resource distribution more strongly than men and thereby strengthen social cohesion in their communities. Bina Agarwal (2010) has published similar findings on women's leadership in community governance in the area of forestry. More specifically, a field experiment in Kenya with a public goods game has shown that women contribute more than men and are less likely than men to extract common pool resources (Abraham Waithima 2012). 
PLEASE QUOTE FROM THE PUBLISHED VERSION: Abena Oduro and Irene van Staveren (2015) "Engendering Economic Policy in Africa", Feminist Economics 21 (3), pp. 1-22.

Lecoutere, d'Exelle, and van Campenhout's findings (2015) speak to both transformations. First, they point out the importance of diversification to nonfarm income among poor rural populations because that enables them to better deal with negative shocks such as water shortages. It also enables them to confront threats to their livelihoods that undermine the norms of fairness, which bind communities, and therefore could risk conflict. Second, they demonstrate that more leadership from women in community-resource governance reduces free riding and reinforces traditional fairness norms allowing the most disadvantaged to have sufficient resources to maintain minimum livelihoods. In other words, women in leadership roles in resource governance will help to ensure equity, but can only achieve this with diversification of income sources of the poor.

The study by Bilisuma Bushie Dito (2015; this volume) on household determinants of women's health in Ethiopia is also about social cohesion. It finds that the most important determinants of women's health are not individual assets brought to marriage or the freedom to choose their husbands. Instead, it is about the social capital of these women's families. This finding offers a more detailed relationship than is commonly tested in the empirical literature on social capital and health. The findings are very much in line with the results for South Korea (Sehee Han, Haeseung Kim, and Hee-Sun Lee 2012) and a cross-country study (Stephen P. Knowles and P. Dorian Owen 2010). Dito finds that living in their own birthplace and having brothers appears to contribute positively to women's health status. Also playing a role are education and a lower age gap with their husbands. Furthermore, when women choose their husbands rather than being in an arranged marriage, these women apparently lose the support of their family because they have gone against the social norm of arranged marriages. So, free choice has a social capital cost, which materializes in women's lower health status. Dito's study 
PLEASE QUOTE FROM THE PUBLISHED VERSION: Abena Oduro and Irene van Staveren (2015) "Engendering Economic Policy in Africa", Feminist Economics 21 (3), pp. 1-22.

shows that policies focused on investment in women as individuals, as independent from their social networks, may actually trigger counterproductive reactions, as long as dominant social norms remain unaddressed. This is another variation on the same mechanism found in two other contributions to this special issue, namely those by Aluko and Nkwake. The two social transformations will not occur with policies treating women as individual sources of human capital that need investment; they will only emerge when gender norms change and women will no longer be punished for making their own choices.

\section{Constraint 4: Macroeconomic trends and shocks}

The fourth and final constraint the contributions in the special issue address concern the macroeconomic context and how the government responds to changes in this context. Allison Loconto's (2015; this volume) contribution analyzes the impact of a well-meaning fair trade strategy on workers on tea plantations in Tanzania, a country where 50 percent of tea is grown under fair trade conditions. She finds that fair trade standards do not provide value added to the existing labor laws and do not ensure gender equality beyond basic labor rights. Instead, her research finds that the trends of mechanization and higher-skill needs would make women's jobs more vulnerable than men's jobs. Moreover, her study finds that women are largely underrepresented in management positions in tea production; therefore it is unlikely the threat of mechanization to gender equality will be raised and addressed at the firm level. Loconto's study demonstrates that fair trade standards cannot address the bigger changes occurring in the tea value chain. This would call for government action as well as a greater responsibility from importing countries to reduce the protection of markets against processed tea. The only way to 
PLEASE QUOTE FROM THE PUBLISHED VERSION: Abena Oduro and Irene van Staveren (2015) "Engendering Economic Policy in Africa", Feminist Economics 21 (3), pp. 1-22.

remedy the situation would be for Tanzania to move up the value chain and to compensate for job losses among unskilled workers due to mechanization with new jobs in processing and other activities higher up the value chain: consider jobs on the assembly line of tea packaging and iced tea production as well as diversification outside the tea sector in other food and non-food value chains in off-farm employment (see, for example, a recent FAO study on this by Elisendra Estruch and Illeana Grandelis [2013]). This would be a good example of the diversification called for by the AfDB and ACET. At the same time, it would help the second transformation, namely reducing poverty and inequality by creating higher value added jobs with higher wages. This strategy may reduce growth in the short run, but it is likely to increase growth in the long run, according to a model developed by Stephanie Seguino and Mark Setterfield (2010).

The study by Ismaël Fofana (2015; this volume) takes an oil price shock as the starting point of a model simulation for the South African economy. He shows that an oil-importing country like South Africa clearly suffers from a doubling of the oil price, but the government policy response matters. His model shows that women's jobs suffer more than men's jobs because they are largely in the non-trade sector, including the public sector. But when the government makes an effort to protect these jobs, by running a budget deficit, the negative effect on women's employment is reduced. His study shows that government responses to macroeconomic trends and shocks make a difference for gender equality. This is even more important because an oil-price shock will also increase women's unpaid work burden because households will substitute more expensive oil-price related inputs bought in the market with more unpaid work. This happens, for example, when substituting cooking fuel with collecting firewood and substituting purchasing bus tickets with walking to the market. Fofana's simulation model thereby nicely illustrates how a seemingly gender-neutral price shock, not induced by any 
PLEASE QUOTE FROM THE PUBLISHED VERSION: Abena Oduro and Irene van Staveren (2015) "Engendering Economic Policy in Africa", Feminist Economics 21 (3), pp. 1-22.

macroeconomic policy, can have serious gendered effects. And when such effects are not compensated by price subsidies and other (temporary) government policies, the transformation of economic growth toward lower poverty levels and less inequality will not be realized. It is precisely a gender analysis of price shock effects on both paid and unpaid work that reveals this fact. The value added to the literature is that the origin of the change does not stem from any macroeconomic strategy, such as liberalization, privatization, or removal of a subsidy, but from an exogenous price shock and understanding that the effect can be relatively easily mitigated.

\section{FROM FORMAL TO INFORMAL INSTITUTIONS AND FROM INDIVIDUAL TO SOCIAL LEVEL POLICY FOCUS}

Structural transformation toward combined growth and gender equality cannot result from rights and regulations alone, even with adequate enforcement. Equal rights and access to resources for women can support economic growth. In particular, equal school enrollment for girls as compared to boys increases average human capital in the labor force, which helps to improve average labor productivity (Stephan Klasen 2002; Esther Duflo 2012). Similarly, when women have solid rights over the land they work, they are more likely to invest in the quality of the land. This contributes to higher yields (Cheryl Doss, Gale Summerfield, and Dzodzi Tsikata 2014). Furthermore, credit can help women entrepreneurs improve their businesses in a variety of ways, leading to their contributing to greater household income and perhaps business expansion (Donna Kelly, Candida Brush, Patricia Greene, and Yana Litovksy 2012). At the same time, economic growth can support gender equality (Günseli Berik, Yana van der Meulen Rogers, and Stephanie Seguino 2010; Irene van Staveren 2011). Higher levels of GDP enable higher tax 
PLEASE QUOTE FROM THE PUBLISHED VERSION: Abena Oduro and Irene van Staveren (2015) "Engendering Economic Policy in Africa", Feminist Economics 21 (3), pp. 1-22.

revenues, which can help finance more girls' school enrollment, land titling, and credit

programs. Additionally, economic growth often generates employment, with opportunities for both men and women (Naila Kabeer and Luisa Natali 2013).

Neither of these two directions of the relationship between growth and gender equality occur automatically. Win-win outcomes need to be enforced and are never automatic. However, win-win outcomes for growth and gender equality cannot be enforced through more rights and regulations, or even stronger enforcement. This is because gender inequality is not a matter of formal institutions. The contributions to this special issue demonstrate that gender inequality relies on unwritten but dominant social norms, hence, informal institutions. Without affecting the dominant asymmetric norms in societies (for example, norms that do not affect different social groups in the same way), growth is not likely to become inclusive for women and will certainly not be socially transformative.

Some African countries uphold asymmetric laws that constrain women's agency. Certain laws exist requiring a woman to obtain her husband's permission before she can open a banking account, and husbands can oppose wives' choice of occupation (Mary Hallward-Driemeier 2012). Moreover, many African countries, including some with asymmetric laws, suffer from asymmetric institutions, in particular gendered informal ones. These include widespread child marriage (under the age of 19), practices of female genital mutilation in some regions, widespread domestic violence, and masculinity ideals tied to household headship, breadwinnership, and the number of (male) children. These gendered, informal institutions determine the gendered division of labor. First, consider in the household how men and women divide up paid and unpaid work. For example, Nkwake's (2015) study on fathers' involvement in childcare in Uganda shows the dominance of the norm that mothers spend much more time than 
PLEASE QUOTE FROM THE PUBLISHED VERSION: Abena Oduro and Irene van Staveren (2015) "Engendering Economic Policy in Africa", Feminist Economics 21 (3), pp. 1-22.

fathers providing childcare. Second, consider the labor market, where women are concentrated in low-end jobs, largely in the informal economy and non-tradable sectors. Loconto's (2015) study on fair trade standards in tea production in Tanzania illustrates how mechanization creates new job opportunities for technically skilled workers, who are almost always men, while workers who hand-pick the tea in the fields will find less and less employment, and these tea field workers are very often women.

The gendered informal institutions also affect patterns of reward. Where women's major role is seen to be in the household, focusing on childcare, food provisioning from the land around the house, and cooking and cleaning, women are not seen as in need of cash, savings, or financial independence. This is often reinforced by inheritance laws and practices, making women dependent upon their brothers or sons rather than inheriting in their own right. Aluko's (2015) study on women's land rights and incomes in Nigeria shows how informal property rights systems among the Yoruba support patriarchy in a variety of ways, overriding formal property rights. An earlier study on gender norms among the Yoruba has also shown how these constrain women's decision-making power (Sunbo Odebode and Irene van Staveren 2007).

Finally, gendered informal institutions affect the opportunities of men and women in the economy. The double role of women, with a high, unpaid workload in addition to the expectation to provide herself and her children with basic needs, provides a serious constraint on her opportunities. First of these is a time constraint. The combined paid and unpaid workday of the average African woman is longer than that for the average African man, particularly in rural areas (C. Mark Blackden and Quintin Wodon 2006). Second, there is a mobility constraint. With the nearly sole responsibility for childcare, women cannot easily travel far for better sales 
PLEASE QUOTE FROM THE PUBLISHED VERSION: Abena Oduro and Irene van Staveren (2015) "Engendering Economic Policy in Africa", Feminist Economics 21 (3), pp. 1-22.

markets for their products or to find employment (see, on South Africa, Taryn Dinkelman, 2011). Additionally, social norms constrain traveling for women (Gina Porter 2011).

Gendered, informal institutions involve the gender division of labor, asymmetric patterns of rewards, and asymmetric opportunities for men and women. As a response, many African countries have developed gender policies, and donors support women's empowerment programs in support of such gender policies. Key components of women's empowerment programs are equal property rights, access to education at all levels, and equal access to credit. These are all hoped to increase and strengthen women's employment and incomes. However, much of these efforts are based on an individualistic paradigm of empowerment as individual autonomy. It assumes that when women become more financially independent from men, educated and with their own assets and income, this will gradually undermine the asymmetric informal institutions that greatly constrain women. This individualistic approach to empowerment is supported with more equal formal institutions, such as equal land rights, equal inheritance rights, free education for all, and laws against domestic violence. These formal institutions are assumed to improve women's fallback position in case of separation, divorce, widowhood, or domestic violence. But is this indeed an effective approach toward women's empowerment and gender equality?

The contributions to this volume raise questions about this policy paradigm that is on the one hand individualistic, and on the other hand relying only on formal institutional change. Nkwake (2015) argues that fathers who perceive their wives to be richer, do not spend more hours in childcare. Apparently, more income or assets do not function as bargaining power to reduce women's high unpaid workload, vis-a-vis their male partners. At most, they have gained the opportunity to pay outside parties - a third person - to help with childcare and homework. Aluko explains how successful businesswomen become increasingly responsible for household 
PLEASE QUOTE FROM THE PUBLISHED VERSION: Abena Oduro and Irene van Staveren (2015) "Engendering Economic Policy in Africa", Feminist Economics 21 (3), pp. 1-22.

expenditures without hope to accumulate assets in their own name. Their male partners' assets remain protected by customary law, which the increased bargaining power of women cannot affect. Loconto shows how adequate implementation of labor standards has no effect on the fact that women do the lower paid jobs and men perform the higher paid jobs. Only upgrading along the value chain alongside changes in gender norms driving occupational segregation will show to be effective. This requires sectoral shifts from agricultural production to processing and active policies against gender stereotyping at work.

The special issue makes clear that gender policies that only rely on more equal formal institutions and take an individualistic view of women's empowerment do not necessarily affect gendered informal institutions, and they thereby do not necessarily contribute to the social transformation needed to happen to make growth inclusive.

When men perceive their masculinity threatened rather than transformed, women may gain jobs and assets, but neither the individual agency nor the collective agency enjoy the benefits of these resources in their economic and social lives. The constraints of informal institutions for women's empowerment have been demonstrated at the cross-country level (Irene van Staveren 2013) as well as for individual countries in Sub-Saharan Africa (for Ethiopia, see Mabsout and van Staveren [2010]; for Burkina Faso, see Harounan Kazianga and Zaki Wahhaj [2013]; for Tanzania, see Seema Vyas, Jessie Mbwambo, and Lori Heise [2015]). That is why economic policies urgently need to address the dominant gendered informal institutions in Africa. A number of actions can be taken in this regard. A first step is to remove formal laws discriminating against women. The continued existence of formal laws that discriminate against work provides legitimacy for informal asymmetric institutions. Moreover, existing gender equal laws require consistent enforcement, something, which is lacking in many African countries 
PLEASE QUOTE FROM THE PUBLISHED VERSION: Abena Oduro and Irene van Staveren (2015) "Engendering Economic Policy in Africa", Feminist Economics 21 (3), pp. 1-22.

around the minimum marriage age, female genital mutilation practices, and domestic violence for example. Second, awareness campaigns and social contracts with local communities can be introduced to change behavior and cultural norms and practices. A clear understanding of the particular institutional binding constraint on women's agency will be required to inform decisions being made on what policies to introduce. This is because different norms and values have different effects on different dimensions of gender inequality. For example, health may be affected more by norms about land rights, whereas education may be affected more by norms around child marriage (van Staveren 2013). Success in reducing the practice of female genital mutilation, or FGM, in Sahel countries has been made through dialogue and involvement of religious leaders at village level (United Nations Children Fund [UNICEF] 2005). Change is slow, but it does happen. In Ghana, the Intestate Succession Act (Law 111) was introduced in 1985 to avoid the injustices that widows experience when their husbands died before having made a will. Despite the weaknesses of the law in its design and the difficulties women have in making recourse to it (Jeanmarie Fenrich and Tracy E. Higgens 2002), its enactment has brought about some behavioral change. Agnes Quisumbing, Ellen Payongayong, J.B. Aidoo, and Keijiro Otsuka (2001) in a study of farming households in the Western Region of Ghana found that about 41 percent of Akan households who traditionally tend to practice matrilineal inheritance distributed inherited property using the law. In a more recent study using a sample of widows in four villages in the Greater Accra Region and Central Region a much smaller proportion of widows reported that Law 111 informed the distribution of their deceased spouse's estate. The incidence of the application of Law 111 is higher among widows who know about the law (Edward Kutsoati and Randall Morck 2012). This suggests that the introduction of laws aimed at eroding the fabric of asymmetric cultural norms and practices must be accompanied by effective 
PLEASE QUOTE FROM THE PUBLISHED VERSION: Abena Oduro and Irene van Staveren (2015) "Engendering Economic Policy in Africa”, Feminist Economics 21 (3), pp. 1-22.

public awareness strategies that discuss their intended effects, benefits, and potential costs. Third, economic policies should be designed to create incentives for behavior change that translates into changes in informal institutions. The narrowing of the gender gap in primary school enrolment in many African countries can be attributed among other things to the education subsidies that reduce the direct costs of schooling and financed the construction of education infrastructure that reduced the distances to access schools (Peter Glick 2008). In Nigeria, for example, Jane A. Lincove (2009) finds an inverse relationship between distance to primary school and the probability of boys and girls ages 6-12 years being enrolled in school. The successful design of policies that intend to encourage behavior change is premised on policymakers being cognizant of and understanding the implications of gendered contexts on growth, development, poverty reduction and the well-being of the entire citizenry.

\section{CONCLUSION}

It is only when gendered informal institutions become symmetric between women and men that the gender division of labor will become fluid and more pragmatic rather than ideological; rewards for work will become more determined by productivity rather than segmentation; and opportunities for women and men, fathers and mothers, will become more equal. Without policies focusing on the transformation of gendered informal institutions, empowerment policies and economic growth are not likely to bring the social transformation of poverty reduction and more equality, benefitting men and women alike.

Abena D. Oduro

Department of Economics, University of Ghana 
PLEASE QUOTE FROM THE PUBLISHED VERSION: Abena Oduro and Irene van Staveren (2015) "Engendering Economic Policy in Africa", Feminist Economics 21 (3), pp. 1-22.

P.O. Box LG57, Legon

Ghana

e-mail:aoduro@ug.edu.gh

Irene van Staveren

Institute of Social Studies, Erasmus University Rotterdam

P.O. Box 29776, The Hague, 2502 LT, Netherlands

e-mail: staveren@iss.nl

\section{ACKNOWLEDGMENTS}

This special issue was made possible by the generous support of a grant to Feminist Economics by the Swiss Agency for Development Cooperation (SDC). This grant helped funding the whole process, including author workshops with expert discussants in Cape Town (South Africa) and Palo Alto (USA). All authors benefitted greatly from the feedback and discussions. We are also grateful for the careful comments and criticism that we received on this introduction from the editors, Diana Strassmann and Günseli Berik, and for their support and that of the journal staff at all moments, from the conception to finalization of this special issue. Finally we also greatly acknowledge the support by the IAFFE office for handling the financial support.

\section{NOTES ON CONTRIBUTORS}

Abena D. Oduro is Senior Lecturer at the Department of Economics and Director of the Centre for Social Policy Studies, University of Ghana. She is co-author of Measuring the Gender Asset Gap in Ghana (University of Ghana and Woeli Publishing Services, 2011). Her current research interests are women and entrepreneurship and gender and asset ownership. 
PLEASE QUOTE FROM THE PUBLISHED VERSION: Abena Oduro and Irene van Staveren (2015) "Engendering Economic Policy in Africa", Feminist Economics 21 (3), pp. 1-22.

Irene van Staveren is Professor of Pluralist Development Economics at the Institute of Social Studies of Erasmus University Rotterdam. She works on development economics as well as ethics and economics, and in both often takes a gender perspective, which has led her to work on unpaid work and care and the integration of the ethics of care in economic thought. She recently published a pluralist introduction to economics in which feminist economics is integrated (Economics after the Crisis, Routledge, 2015).

\section{REFERENCES}

Agarwal, Bina. 2010. Gender and Green Governance. The Political Economy of Women's Presence Within and Beyond Community Forestry. Oxford: Oxford University Press. African Center for Economic Transformation (ACET). 2014. 2014 African Transformation Report: Growth with Depth. Accra, Ghana: African Center for Economic Transformation. http://acetforafrica.org/wp-content/uploads/2014/03/2014-African-TransformationReport.pdf.

African Development Bank Group (AfDB). 2012. Briefing Notes for AfDB's Long-Term Strategy: Briefing Note 6: Inclusive Growth Agenda. Abidjan 01, Côte d'Ivoire: African Development Bank Group. http://www.afdb.org/fileadmin/uploads/afdb/Documents/PolicyDocuments/FINAL\%20Briefing\%20Note\%206\%20Inclusive\%20Growth.pdf. 2013. At the Center of Africa's Transformation: Strategy for 2013-22. Abidjan 01, Côte d'Ivoire: African Development Bank Group. http://www.afdb.org/fileadmin/uploads/afdb/Documents/Policy- 
PLEASE QUOTE FROM THE PUBLISHED VERSION: Abena Oduro and Irene van Staveren (2015) "Engendering Economic Policy in Africa", Feminist Economics 21 (3), pp. 1-22.

Documents/AfDB_Strategy_for_2013-2022_-

_At_the_Center_of_Africa's_Transformation.pdf.

African Development Bank Group, African Union Commission, and Economic Commission for Africa. 2014. African Statistical Yearbook. African Statistical Coordination Committee (ASCC). http://www.afdb.org/en/documents/document/african-statistical-yearbook-2014$\underline{47648 / .}$

Aluko, Yetunde. 2015. "Patriarchy and Property Rights among Yoruba Women in Nigeria." Feminist Economics 21(3). DOI: 10.1080/13545701.2015.1015591.

Bardasi, Elena and Quentin Wodon. 2010. "Working Long Hours and Having No Choice: Time Poverty in Guinea." Feminist Economics 16(3): 45-78.

Berik, Günseli, Yana van der Meulen Rogers, and Stephanie Seguino, eds. 2010. Inequality, Development, and Growth. London: Routledge.

Blackden, C. Mark and Quintin Wodon. 2006. “Gender, Time-Use, and Poverty in SubSaharan Africa.” Working Paper 73, World Bank.

Dinkelman, Taryn. 2011. "The Effects of Rural Electrification on Employment: New Evidence from South Africa", American Economic Review 101 (7), pp. 3078-3108.

Dito, Bilisuma Bushie. 2015. “Women's Intrahousehold Decision-Making Power and Their Health Status: Evidence from Rural Ethiopia.” Feminist Economics 21(3). DOI: 10.1080/13545701.2015.1007073.

Doss, Cheryl. 2006. "The Effects of Intrahousehold Property Ownership on Expenditure Patterns in Ghana." Journal of African Economies 15(1): 149-80.

Doss, Cheryl, Chiara Kovarik, Amber Peterman, Agnes Quisumbing, and Mara van den Bold. 
PLEASE QUOTE FROM THE PUBLISHED VERSION: Abena Oduro and Irene van Staveren (2015) "Engendering Economic Policy in Africa", Feminist Economics 21 (3), pp. 1-22.

2015. "Gender Inequalities in Ownership and Control of Land in Africa: Myth and Reality." Agricultural Economics 46(3): 403-34.

Doss, Cheryl, Gale Summerfield, and Dzodzi Tsikata, eds. 2014. 'Land, Gender, and Food Security." Special issue, Feminist Economics 20(1).

Duflo, Esther. 2012. “Women's Empowerment and Economic Development.” Journal of Economic Literature 50(4): 1051-79.

Estruch, Elisendra and Illeana Grandelis. 2013. "Promoting Economic Diversification and Decent Rural Employment Towards Greater Resilience to Food Price Volatility.” Food and Agriculture Association (FAO) Discussion Paper. http://www.fao.org/fileadmin/user_upload/fao_ilo/pdf/Papers/DRE_Food_Price_Volatilit y.pdf.

Fenrich, Jeanmarie and Tracy E. Higgins. 2002. "Promise Unfulfilled: Law, Culture and Women's Inheritance Rights in Ghana.” Fordham International Law Journal 25(2): 259341.

Floro, Maria S. and Hitomi Komatsu. 2011. "Gender and Work in South Africa: What Can Time-Use Data Reveal?” Feminist Economics 17(4): 33-66.

Fofana, Ismaël. 2015. “Gender Analysis of the Policy Responses to High Oil Prices: A Case Study of South Africa." Feminist Economics 21(3). DOI:

10.1080/13545701.2015.1023330.

Fosu, A.K. 2011. “Growth, Inequality, and Poverty Reduction in Developing Countries: Recent Global Evidence.” WIDER Working Paper 2011/01, UNU-WIDER. Fontana, Marzia and Luisa Natali. 2008. “Gendered Patterns of Time Use in Tanzania: Public 
PLEASE QUOTE FROM THE PUBLISHED VERSION: Abena Oduro and Irene van Staveren (2015) "Engendering Economic Policy in Africa", Feminist Economics 21 (3), pp. 1-22.

Investment in Infrastructure Can Help.” Paper prepared for the International Food Policy

Research Instituted (IFPRI) Project on "Evaluating the Long-Term Impact of GenderFocused Policy Interventions."

https://www.ids.ac.uk/files/dmfile/genderedpatternsoftimeuseintanzaniapublicinv estmentininfrastructurecanhelp.pdf.

Glick, Peter. 2008. "What Policies will Reduce Gender Schooling Gaps in Developing Countries: Evidence and Interpretation.” World Development 36 (9): 1623-1646.

Goldstein, Markus and Christopher Udry. 2008. "The Profits of Power: Land Rights and Agricultural Investment in Ghana.” Journal of Political Economy 116(6): 981-1022. Hallward-Driemeier, Mary. 2013. Enterprising Women; Expanding Economic Opportunities in Africa. Washington, DC: World Bank.

Han, Sehee, Haeseung Kim, and Hee-Sun Lee. 2012. “A Multilevel Analysis of Social Capital and Self-Reported Health: Evidence from Seoul, South Korea.” International Journal for Equity in Health 11(3): 1-12.

Harttgen, Kenneth, Stephan Klasen, and Sebastian Vollmer. 2012. "Economic Growth and Child Undernutrition in Africa." Working Paper 2012-013. New York: United Nations Development Programme, Regional Bureau for Africa.

Hofstede, Geert. 2001. Culture's Consequences: Comparing Values, Behaviors, and Organizations Across Nations. $2^{\text {nd }}$ edition. Thousand Oaks, CA: Sage.

IMF. 2014. World Economic Outlook Database October 2014. http://www.imf.org/external/pubs/ft/weo/2014/02/weodata/weoselagr.aspx 
PLEASE QUOTE FROM THE PUBLISHED VERSION: Abena Oduro and Irene van Staveren (2015) "Engendering Economic Policy in Africa", Feminist Economics 21 (3), pp. 1-22.

Jacobs, Krista and Aslihan Kes. 2014. “The Ambiguity of Joint Asset Ownership: Cautionary Tales From Uganda and South Africa.” Feminist Economics 21(3). DOI: 10.1080/13545701.2014.926559.

Kabeer, Nail and Luisa Natali. 2013. "Gender Equality and Economic Growth: Is There a Win-Win?” IDS Working Paper 417. Brighton: Institute of Development Studies. Kazianga, Harounan and Zaki Wahhaj. 2013. “Gender, Social Norms and Household Production in Burkina Faso." Economic Development and Cultural Change 61(3): $539-76$.

Kelley, Donna J., Candida G. Brush, Patricia G. Greene, and Yana Litovsky. 2013. Global Entrepreneurship Monitor. 2012 Women's Report. London: Global Entrepreneurship Research Association (GERA). http://www.babson.edu/Academics/centers/blankcenter/global-research/gem/Documents/GEM\%202012\%20Womens\%20Report.pdf.

Klasen, Stephan. 2002. "Low Schooling for Girls, Slower Growth for All? Cross-Country Evidence on the Effect of Gender Equality in Education on Economic Development." World Bank Economic Review 16(3): 345-73.

Klasen, Stephan and Francesca Lamanna. 2009. “The Impact of Gender Inequality in Education and Employment on Economic Growth: New Evidence for a Panel of Countries." Feminist Economics 15(3): 91-132.

Knowles, Stephen and P. Dorian Owen. 2010. "Which Institutions are Good for Your Health? The Deep Determinants of Comparative Cross-country Health Status.” Journal of Development Studies 46(4): 701-23.

Kutsoati, Edward and Randall Morck. 2012. "Family Ties, Inheritance Rights, and Successful 
PLEASE QUOTE FROM THE PUBLISHED VERSION: Abena Oduro and Irene van Staveren (2015) "Engendering Economic Policy in Africa", Feminist Economics 21 (3), pp. 1-22.

Poverty Alleviation: Evidence from Ghana.” National Bureau of Economic Research

(NBER) Working Paper 18080. http://www.nber.org/papers/w18080.

Lagarde, Christine. 2014. “Africa Rising-Building to the Future.” Keynote Address by

Managing Director, International Monetary Fund, May 29, Maputo, Mozambique. http://www.imf.org/external/np/speeches/2014/052914.htm.

Lakner, Christoph, Mario Negre, and Espen Beer Prydz. 2014. "Twinning the Goals - How Can Promoting Shared Prosperity Help to Reduce Global Poverty?” Policy Research Working Paper 7106, World Bank.

Lecoutere, Els, Ben D’Exelle, and Bjorn Van Campenhout. 2015. “Sharing Common Resources in Patriarchal and Status-Based Societies: Evidence from Tanzania.” Feminist Economics 21(3). DOI: 10.1080/13545701.2015.1024274.

Lincove, Jane A. 2009. "Determinants of Schooling for Boys and Girls in Nigeria Under a Policy of Free Primary Education.” Economics of Education Review 28(4): 474-84.

Loconto, Allison. 2015. “Can Certified-Tea Value Chains Deliver Gender Equality in Tanzania?" Feminist Economics 21(3). DOI: 10.1080/13545701.2014.1001765.

Mabsout, Ramzi and Irene van Staveren. 2010. "Disentangling Bargaining Power from Individual and Household Level to Institutions: Evidence on Women's Position in Ethiopia." World Development 38(5): 783-96.

Nkwake, Apollo M. 2015. "Spousal Wealth and Fathers' Involvement in Childcare in Uganda." Feminist Economics 21(3).

Odebode, Sunbo and Irene van Staveren. 2007. “Gender Norms as Asymmetric Institutions. A Case Study of Yoruba Women in Nigeria.” Journal of Economic Issues 41(4): 903-25. 
PLEASE QUOTE FROM THE PUBLISHED VERSION: Abena Oduro and Irene van Staveren (2015) "Engendering Economic Policy in Africa", Feminist Economics 21 (3), pp. 1-22.

Oduro, Abena D., William Baah-Boateng, and Louis Boakye-Yiadom. 2011. Measuring the Gender Asset Gap in Ghana. Accra, Ghana: Woeli Publishing Services and Royal Crown Printing Press.

Omeje, Joachim, C., Sarah N. Oshi, and Daniel C. Oshi. 2011. "Does Possession of Assets Increase Women's Participation in Reproductive Decision-Making: Perceptions of Nigerian Women.” Journal of Biosocial Science 43(1): 101-11.

Quisumbing, Agnes, Ellen Payongayong, J.B. Aidoo, and Keijiro Otsuka. 2001. “Women’s Land Rights in the Transition to Individualized Ownership: Implications for Tree Resource Management in Western Ghana.” Economic Development and Cultural Change 50(1): 157-81.

Porter, Gina. 2011. “'I Think a Woman Who Travels A Lot Is Befriending Other Men and That's Why She Travels': Mobility Constraints and Their Implications for Rural Women and Girls in Sub-Saharan Africa." Gender, Place and Culture a Journal of Feminist Geography 18(1): 65-81.

Seguino, Stephanie and Mark Setterfield. 2010. “Gender Equality and the Sustainability of Steady State Growth Paths.” In Handbook of Alternative Theories of Economic Growth, edited by Mark Setterfield, 360-75. Cheltenham, UK: Edward Elgar.

Seguino, Stephanie and Maureen Were. 2014. "Gender, Economic Growth, and Development in Sub-Saharan Africa." In The Oxford Handbook of Africa and Economics, Volume 2: Policies and Practices, edited by Célestin Monga and Justin Yifu Lin, 571-87.Oxford: Oxford University Press.

United Nations Children Fund (UNICEF). 2005. Changing a Harmful Social 
PLEASE QUOTE FROM THE PUBLISHED VERSION: Abena Oduro and Irene van Staveren (2015) "Engendering Economic Policy in Africa", Feminist Economics 21 (3), pp. 1-22.

Convention: Female Genital Mutilation/Cutting. Edited by Alexia Lewnes. Sesto

Fiorentino, Italy: ABC Tipografia. http://www.unicefirc.org/publications/pdf/fgm_eng.pdf.

United Nations Development Programme (UNDP). 2012. Africa Human Development Report

2012: Towards a Food Secure Future. New York: UN Publications.

http://www.za.undp.org/content/dam/south_africa/docs/hdr/UNDP-Africa\%20HDR-

2012-EN.pdf.

—. 2014. Human Development Report 2014. Sustaining Human Progress: Reducing

Vulnerabilities and Building Resilience. New York: UN Publications.

http://www.arabstates.undp.org/content/dam/rbas/report/HDR-2014-English.pdf.

United Nations Economic Commission for Africa (UNECA). 2015. Economic Report on Africa

2015: Industrializing through Trade. Addis Ababa: United Nations Economic

Commission for Africa.

http://www.uneca.org/sites/default/files/publications/era2015_eng_fin.pdf

van Staveren, Irene. 2011. "From Gender as Exogenous to Gender as Endogenous in the

New Economics.” In New Economics as Mainstream Economics, edited by Philip

Arestis and Malcolm Sawyer, 116-53. Basingstoke: Palgrave Macmillan.

—. 2013. "An Exploratory Cross-Country Analysis of Gendered Institutions.”

Journal of International Development 25(1): 108-21.

—. 2014. "Gender as a Macro Economic Variable.” In New Frontiers in Feminist

Political Economy, edited by Shirin M. Rai and Georgina Waylen, 135-53. London:

Routledge.

Vyas, Seema, Jessie Mbwambo, and Lori Heise. 2015. “Women's Paid Work and Intimate

Partner's Violence: Insights from Tanzania.” Feminist Economics 21(1): 35-58. 
PLEASE QUOTE FROM THE PUBLISHED VERSION: Abena Oduro and Irene van Staveren (2015) "Engendering Economic Policy in Africa", Feminist Economics 21 (3), pp. 1-22.

Waithima, Abraham K. 2012. "The Role of Harambee Contributions in Corruption:

Experimental Evidence from Kenya.” Investment Climate and Business Environment Research Fund (ICBE-RF) Research Report 16/12.

Wamboye, Evelyn F. and Stephanie Seguino. 2014. "Gender Effects of Trade Openness in SubSaharan Africa.” Feminist Economics 21(3). DOI: 10.1080/13545701.2014.927583.

\section{NOTES}

${ }^{1}$ The focus of this special issue is on Sub-Saharan Africa. Africa and Sub-Saharan Africa will be used interchangeably.

${ }^{2}$ East Asia and Pacific, Europe and Central Asia, Latin America and the Caribbean, Middle East, and North Africa and South Asia.

${ }^{3}$ http://zeropoverty2030.org/the-campaign/.

${ }^{4}$ ACET is a think tank that conducts research on issues surrounding economic transformation. It provides advisory support to governments and undertakes advocacy work.

${ }^{5}$ A study among married Igbo women in southeastern Nigeria arrives at similar conclusions (Joachim C. Omeje, Sarah N. Oshi, and Daniel C. Oshi 2011). Individual ownership of assets such as vehicles, farmland, milling machines, and televisions does not increase women's participation in reproductive decision -making because husbands control how revenue generated from the assets is spent. The study, however, does not investigate whether the assets were acquired through inheritance or purchase. 